\title{
Response of Urdbean [Vigna mungo (L.) Hepper] to Phosphorus Fertilization and Thiourea on Yield, Quality, Nutrient Content and Uptake
}

\author{
Sanju Choudhary $^{1 *}$, O.P. Sharma ${ }^{1}$, Gopal Lal Choudhary ${ }^{2}$ and Lali Jat ${ }^{1}$ \\ ${ }^{1}$ Department of Agronomy, S.K.N. College of Agriculture, SKNAU, Jobner- 303329, India \\ ${ }^{2}$ Department of Agronomy, Rajasthan College of Agriculture, MPUA\&T, \\ Udaipur- 313001, India \\ *Corresponding author
}

\begin{tabular}{|c|c|}
\hline & A B S T R A C T \\
\hline & \multirow{7}{*}{$\begin{array}{l}\text { A field experiment was conducted during Kharif season of } 2015 \text { on loamy sand soil to } \\
\text { study the effect of phosphorus levels and thiourea on productivity, nutrient content and } \\
\text { uptake of urdbean. Experiment consisted of four treatments of phosphorus levels }(0,20,40 \\
\text { and } 60 \mathrm{~kg} / \mathrm{ha} \text { ) and five thiourea treatments (control, thiourea } 500 \mathrm{ppm} \text { at branching, } \\
\text { thiourea } 500 \mathrm{ppm} \text { at branching and flowering, thiourea } 1000 \mathrm{ppm} \text { at branching and } \\
\text { thiourea } 1000 \mathrm{ppm} \text { at branching and flowering) thereby making twenty treatment } \\
\text { combinations tested in randomized block design with three replications. Result indicated } \\
\text { that application of phosphorus up to } 40 \mathrm{~kg} / \mathrm{h} \text { significantly increased seed and straw yield, } \\
\text { net returns, protein content in seed, nitrogen, phosphorus and potassium concentration in } \\
\text { seed and straw and total uptake of nitrogen, phosphorus and potassium over preceding } \\
\text { levels and remained at par with } 60 \mathrm{~kg} / \mathrm{ha} \text {. Whereas, raising the level of phosphorus from } 0 \\
\text { to } 20 \mathrm{~kg} / \mathrm{ha} \text { registered the highest agronomic efficiency, apparent recovery and } \\
\text { physiological efficiency of phosphorus after that, it showed significant decline upto } 60 \\
\mathrm{~kg} / \mathrm{ha} \text {. Application of thiourea } 500 \text { ppm at branching and flowering registered significantly } \\
\text { higher concentration of } \mathrm{N} \text { and } \mathrm{P} \text { in seed and straw and total uptake of } \mathrm{N} \text {, P and K as well as } \\
\text { protein content in seed and available } \mathrm{P}_{2} \mathrm{O}_{5} \text { in soil after crop harvest over thiourea ( } 500 \\
\text { ppm) at branching and control. Whereas the highest agronomic efficiency and apperent } \\
\text { recovery of P recorded under thiourea } 500 \text { ppm at branching and flowering and } \\
\text { physiological efficiency under control. }\end{array}$} \\
\hline & \\
\hline & \\
\hline & \\
\hline Article Info & \\
\hline $\begin{array}{l}\text { Accepted: } \\
\text { 23 September } 2017 \\
\text { Available Online: } \\
\text { 10 October } 2017\end{array}$ & \\
\hline & \\
\hline
\end{tabular}

\section{Introduction}

Pulses are the main source of dietary protein particularly for vegetarians and contribute about 14 per cent of the total protein of average Indian diet. Urdbean [Vigna mungo (L.) Hepper] is among the major pulses grown throughout the country during both in summer and rainy season. It is a self-pollinated leguminous crop containing $24 \%$ protein. The duration of the crop is very short; it fits well in various multiple and intercropping systems. After removing pods, its plant may be used as good quality green or dry fodder or green manure. Being a legume, it also enriches soil by fixing atmospheric nitrogen. Phosphorus is a universally deficient plant nutrient in most of the soils of Rajasthan, particular in light textured soils. Application of phosphorus to pulse crop has been found very effective and called as master key element for increasing yield. Its play a vital role in growth and development of roots, phosphorus is also necessary for growth of Rhizobium bacteria 
responsible for biological fixation of $\mathrm{N}$ to increase the efficiency of pulses as soil renovator and serves the dual purpose of increasing yield of main as well as succeeding crop. An adequate supply of phosphorus has been reported well for better growth, yield, quality and enormous nodule formation in legumes (Sammauria et al., 2009). It acts as a structural component of membrane system of cells, chloroplasts and mitochondria. It is a constituent of energy phosphates like ADP and ATP, nucleic acids (DNA and RNA), nucleo proteins, purines, pyrimidine, nucleotides and several coenzymes. About 93-99 per cent of the total phosphorus is insoluble and hence directly not available to plants. Thiourea is a sulphydryl compound (Jocelyn, 1972). It contains one $-\mathrm{SH}$ group $(42.1 \% \mathrm{~S})$ besides containing nitrogen (36.8\%) in the form of $\mathrm{NH}_{2}$ as evident from its structural formula given below.

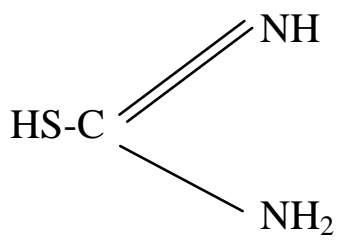

Use of thiourea, recognized as plant growth regulator (Sahu and Solanki, 1991) may be helpful in this regard. The exogenous supply of growth regulators also modifies plant growth by hormonal control, differentiation, morphogenesis and key physiological processes such as carbon and nutrient assimilation, partitioning of photosynthates and utilization efficiency. Soaking of seeds and foliar spray of thiourea have been reported not only to improve growth and development of plants, but also the dry matter partitioning for increased seed yield (Arora, 2004).

\section{Materials and Methods}

A field experiment was conducted during kharif season of 2015 at the Agronomy Farm,
S.K.N. College of Agriculture, Jobner (Rajasthan). Soil of the experimental field was loamy sand in texture with alkaline in reaction $(\mathrm{pH} 8.2)$, low in organic carbon $(0.15 \%)$ and available nitrogen $(132.4 \mathrm{~kg} / \mathrm{ha})$, medium in available phosphorus (16.26 $\mathrm{kg} / \mathrm{ha})$ and potassium (154.2 $\mathrm{kg} / \mathrm{ha})$. Experiment was laid out in randomized block design with twenty treatment combinations comprised of four phosphorus levels $(0,20$, 40 and $60 \mathrm{~kg} / \mathrm{ha}$ ) and five thiourea treatments viz., (control, 500 ppm spray at branching, 500 ppm spray at branching and flowering, 1000 ppm spray at flowering and 1000 ppm spray at branching and flowering). The urdbean variety T-9 was sown using seed rate $15 \mathrm{~kg} / \mathrm{ha}$ with a row spacing of $30 \mathrm{~cm}$ at the depth of 4-5 cm. Uniform dose of nitrogen 25 $\mathrm{kg} / \mathrm{ha}$ was applied to all the plots by adjusting the nitrogen supplied by DAP and remaining through urea at the time of sowing. Whereas, phosphorus was applied as per treatments through DAP. Foliar spray of thiourea was done $500 \mathrm{ppm}$ and $1000 \mathrm{ppm}$ solution at branching and flowering stages as per treatment while applying the spray treatment, teepol $(0.05 \mathrm{ml} / \mathrm{L}$.), a spreading agent was mixed with the spray solution. $\mathrm{N}$ concentration was determined by modified kjeldhal method while total $\mathrm{P}$ determined using sulphuric-nitric-perchloric acid digest procedure. $\mathrm{K}$ was determined by tri acid digestion procedure on flame photometer.

\section{Results and Discussion}

\section{Effect of phosphorus levels}

Successive increase in phosphorus levels significantly increased number of pods/plant, number of seeds/pod, test weight, seed yield, straw yield and biological yield upto 40 $\mathrm{kg} / \mathrm{ha}$, which was comparable with application of highest level of $60 \mathrm{~kg} / \mathrm{ha}$ and no significant effect was observed on harvest index (Table 1). The increase in seed yield with $60 \mathrm{~kg} / \mathrm{ha}$ was 13.4 and $53.5 \%$ over 20 
$\mathrm{kg} / \mathrm{ha}$ and control, respectively. This could be attributed due to better root proliferation, higher root development, increased availability and uptake of nutrients, energy transformation and metabolic processes in plant. The higher crop growth with more supply of phosphorus might regulate starch/sucrose ratio in source leaves and reproductive organs. The beneficial effect of phosphorus on fruiting of plants and better translocation of desired metabolites to the yield contributing parts of the plant might attributed to more seed yield. The improvement in straw yield might be due to the fact that phosphorus tends to increased growth and development in terms of plant height, branches and dry matter by improving nutritional environment of rhizosphere and plant system leading to higher plant metabolism and photosynthetic activity.

These findings corroborate the results of Tanwar et al., (2003), Rathore et al., (2010) and Kumawat et al., (2013) in urdbean and Singh and Sekhon (2007) in mungbean. The application of phosphorus $40 \mathrm{~kg} / \mathrm{ha}$ recorded the significantly higher net returns (Rs. 52267/ha) over preceding levels and remained at par with $60 \mathrm{~kg} / \mathrm{ha}$.

The increase in net returns might be due to higher seed and straw yield obtained under the treatment. A significant increased protein content in seed, nitrogen, phosphorus and potassium concentration in seed and straw and their uptake were observed with the application of phosphorus upto $40 \mathrm{~kg} / \mathrm{ha}$ (Table 2). As stated that application of phosphorus might have nutritional environment in rhizospheric as well as in plant leading to increased uptake and translocation of nutrients especially of $\mathrm{N}, \mathrm{P}$ and $\mathrm{K}$ in reproductive structures which led to higher content and uptake. Further, the significant and positive correlation of yield with nutrients also evidenced for higher content of nutrients. Since, uptake of N, P and
$\mathrm{K}$ is the function of seed and straw yield and their content, the significant increase in concentration of these nutrients coupled with increased seed and straw yield enhanced the total uptake of N, P and K. Protein content is essentially the manifestation of $\mathrm{N}$ concentration in seed. Hence, increased $\mathrm{N}$ concentration might have increased the protein content. These results are close in conformity with the findings of Srinivasarao and Ali (2006) in urdbean and Kumawat et $a l$. , (2014) in greengram. Raising the level of phosphorus from 0 to $20 \mathrm{~kg} / \mathrm{ha}$ registered the highest agronomic efficiency, apparent recovery and physiological efficiency of phosphorus after that, it showed significant decline upto $60 \mathrm{~kg} / \mathrm{ha}$. Whereas, the available phosphorus in soil after crop harvest increased significantly upto $40 \mathrm{~kg} / \mathrm{ha}$ and remained at par with $60 \mathrm{~kg} / \mathrm{ha}$ (Table 3).

\section{Effect of thiourea}

Foliar application of thiourea (Thiourea 500 ppm at branching, $1000 \mathrm{ppm}$ at branching, $500 \mathrm{ppm}$ at branching and flowering and 1000 ppm at branching and flowering) significantly increased yield attributes viz., number of pods per plant and number of seeds per pod over control. Thiourea was applied at both the stages even at lower concentration $(500 \mathrm{ppm}$ at branching and flowering) significantly enhanced the seed yield (1167 kg/ha) over its application at one stage and remained at par with its higher concentration at both the stages. Significant improvement in the seed yield due to foliar spray of $500 \mathrm{ppm}$ thiourea was also reported by Burman et al., (2008) and Bamaniya (2009) in mungbean. While explaining the role of sulphydryl compounds in maize productivity, Sahu and Solanki (1991) were of the view that probably photosynthates transport was improved because of improved dry matter partitioning. The partitioning of dry matter in plants depends on its distribution between leaves, stem and sink. 
Table.1 Effect of phosphorus fertilization and thiourea on yield attributing characters, seed, straw, biological yield, harvest index and net returns

\begin{tabular}{|c|c|c|c|c|c|c|c|c|}
\hline Treatments & $\begin{array}{c}\text { Number of } \\
\text { pods per } \\
\text { plant }\end{array}$ & $\begin{array}{l}\text { Number of } \\
\text { seeds per } \\
\text { pod }\end{array}$ & $\begin{array}{c}\text { Test } \\
\text { weight }\end{array}$ & $\begin{array}{c}\text { Seed } \\
\text { yield } \\
\text { (Kg/ha) }\end{array}$ & $\begin{array}{c}\text { Straw } \\
\text { yield } \\
(\mathrm{Kg} / \mathrm{ha})\end{array}$ & $\begin{array}{c}\text { Biological } \\
\text { yield } \\
(\mathrm{Kg} / \mathrm{ha})\end{array}$ & $\begin{array}{c}\text { Harvest } \\
\text { Index }\end{array}$ & $\begin{array}{c}\text { Net } \\
\text { returns } \\
\text { (Rs./ha) }\end{array}$ \\
\hline \multicolumn{9}{|c|}{ Phosphorus levels (Kg/ha) } \\
\hline Control & 16.7 & 5.9 & 34.2 & 770 & 1516 & 2286 & 33.68 & 28980 \\
\hline 20 & 22.5 & 7.1 & 36.9 & 1042 & 1995 & 3037 & 34.30 & 45254 \\
\hline 40 & 27.2 & 7.8 & 39.2 & 1164 & 2272 & 3436 & 33.87 & 52267 \\
\hline 60 & 28.6 & 8.2 & 39.9 & 1182 & 2317 & 3499 & 33.78 & 52400 \\
\hline SEm \pm & 0.6 & 0.2 & 0.7 & 22 & 51 & 76 & 0.65 & 1100 \\
\hline $\mathrm{CD}(\mathrm{P}=0.05)$ & 1.6 & 0.5 & 2.1 & 62 & 145 & 217 & NS & 3144 \\
\hline \multicolumn{9}{|l|}{ Thiourea } \\
\hline Control & 18.6 & 5.6 & 33.9 & 775 & 1508 & 2283 & 33.93 & 28857 \\
\hline $500 \mathrm{ppm}$ at branching & 22.2 & 6.9 & 36.6 & 1031 & 2015 & 3046 & 33.83 & 44626 \\
\hline $\begin{array}{l}500 \mathrm{ppm} \text { at branching } \\
\text { and flowering }\end{array}$ & 27.4 & 8.1 & 39.8 & 1167 & 2270 & 3437 & 33.95 & 52564 \\
\hline $\begin{array}{l}1000 \mathrm{ppm} \text { at } \\
\text { branching }\end{array}$ & 22.8 & 7.2 & 36.9 & 1039 & 2042 & 3081 & 33.70 & 44739 \\
\hline $\begin{array}{l}1000 \mathrm{ppm} \text { at } \\
\text { branching }\end{array}$ & 27.8 & 8.5 & 40.5 & 1187 & 2290 & 3477 & 34.13 & 52839 \\
\hline $\mathrm{SEm} \pm$ & 0.6 & 0.2 & 0.8 & 24 & 57 & 85 & 0.73 & 1230 \\
\hline $\mathrm{CD}(\mathrm{P}=0.05)$ & 1.8 & 0.6 & 2.4 & 69 & 162 & 242 & NS & 3515 \\
\hline $\mathrm{CV}(\%)$ & 9.15 & 9.86 & 7.60 & 8.05 & 9.72 & 9.59 & 7.45 & 9.53 \\
\hline
\end{tabular}

Table.2 Effect of phosphorus fertilization and thiourea on N, P, K concentration, protein content and their uptake

\begin{tabular}{|c|c|c|c|c|c|c|c|c|c|c|}
\hline \multirow[t]{2}{*}{ Ttreatments } & \multicolumn{2}{|c|}{$\begin{array}{c}\text { N concentration } \\
(\%)\end{array}$} & \multirow{2}{*}{$\begin{array}{c}\text { Total N } \\
\text { uptake } \\
\text { (Kg/ha) }\end{array}$} & \multirow{2}{*}{$\begin{array}{c}\text { Protein } \\
\text { content } \\
(\%)\end{array}$} & \multicolumn{2}{|c|}{$\begin{array}{c}\text { P concentration } \\
(\%)\end{array}$} & \multirow{2}{*}{$\begin{array}{c}\text { Total P } \\
\text { uptake } \\
\text { (Kg/ha) }\end{array}$} & \multicolumn{2}{|c|}{$\begin{array}{c}\text { K concentration } \\
(\%)\end{array}$} & \multirow{2}{*}{$\begin{array}{c}\text { Total K } \\
\text { uptake } \\
\text { (Kg/ha) }\end{array}$} \\
\hline & Seed & Straw & & & seed & straw & & Seed & Straw & \\
\hline \multicolumn{11}{|c|}{ Phosphorus levels (Kg/ha) } \\
\hline Control & 3.11 & 1.40 & 45.59 & 19.44 & 0.350 & 0.166 & 5.28 & 0.765 & 1.617 & 30.45 \\
\hline 20 & 3.41 & 1.56 & 67.26 & 21.31 & 0.388 & 0.185 & 7.83 & 0.846 & 1.760 & 44.00 \\
\hline 40 & 3.66 & 1.68 & 81.51 & 22.88 & 0.418 & 0.199 & 9.50 & 0.899 & 1.864 & 52.90 \\
\hline 60 & 3.74 & 1.70 & 84.36 & 23.38 & 0.420 & 0.210 & 9.95 & 0.908 & 1.877 & 54.31 \\
\hline SEm \pm & 0.05 & 0.03 & 1.94 & 0.36 & 0.006 & 0.004 & 0.20 & 0.013 & 0.027 & 0.85 \\
\hline $\mathrm{CD}(\mathrm{P}=0.05)$ & 0.15 & 0.09 & 5.54 & 1.03 & 0.019 & 0.012 & 0.56 & 0.037 & 0.078 & 2.43 \\
\hline \multicolumn{11}{|l|}{ Thiourea } \\
\hline Control & 3.15 & 1.39 & 45.95 & 19.69 & 0.340 & 0.160 & 5.11 & 0.822 & 1.750 & 33.07 \\
\hline $\begin{array}{l}500 \text { ppm at } \\
\text { branching }\end{array}$ & 3.40 & 1.53 & 66.72 & 21.25 & 0.391 & 0.180 & 7.75 & 0.852 & 1.775 & 44.97 \\
\hline $\begin{array}{l}500 \mathrm{ppm} \text { at } \\
\text { branching and } \\
\text { flowering }\end{array}$ & 3.64 & 1.70 & 81.88 & 22.75 & 0.421 & 0.210 & 9.80 & 0.867 & 1.790 & 51.24 \\
\hline $\begin{array}{l}1000 \mathrm{ppm} \text { at } \\
\text { branching }\end{array}$ & 3.45 & 1.57 & 68.76 & 21.56 & 0.394 & 0.186 & 7.99 & 0.856 & 1.778 & 45.62 \\
\hline $\begin{array}{l}1000 \mathrm{ppm} \text { at } \\
\text { branching }\end{array}$ & 3.76 & 1.73 & 85.10 & 23.50 & 0.424 & 0.214 & 10.05 & 0.875 & 1.804 & 52.19 \\
\hline SEm + & 0.06 & 0.03 & 2.17 & 0.40 & 0.007 & 0.005 & 0.22 & 0.014 & 0.030 & 0.95 \\
\hline $\mathrm{CD}(\overline{\mathrm{P}}=0.05)$ & 0.17 & 0.10 & 6.19 & 1.15 & 0.021 & 0.014 & 0.63 & NS & NS & 2.72 \\
\hline $\mathrm{CV}(\%)$ & 5.75 & 7.30 & 10.77 & 6.42 & 6.370 & 8.73 & 0.93 & 5.86 & 5.93 & 7.25 \\
\hline
\end{tabular}


Table.3 Effect of phosphorus fertilization and thioureaon phosphorus use efficiency andavailable phosphorus in soil after crop harvest

\begin{tabular}{|c|c|c|c|c|}
\hline Treatments & $\begin{array}{c}\text { Agronomic } \\
\text { efficiency of P } \\
(\mathrm{kg} \mathrm{seed} / \mathrm{kg} \mathrm{P})\end{array}$ & $\begin{array}{c}\text { Apperent } \\
\text { recovery of } \\
\mathbf{P}(\%)\end{array}$ & $\begin{array}{c}\text { Physiological } \\
\text { efficiency of } P(\mathrm{~kg} \\
\text { seed/kg uptake of } P \text { ) }\end{array}$ & $\begin{array}{c}\text { Available } \\
\mathbf{P}_{2} \mathbf{O}_{5} \\
(\mathbf{k g} / \mathbf{h a})\end{array}$ \\
\hline \multicolumn{5}{|l|}{ Phosphorus levels (kg/ha) } \\
\hline Control & - & - & - & 15.02 \\
\hline 20 & 13.60 & 12.77 & 108.73 & 17.10 \\
\hline 40 & 9.85 & 10.57 & 95.15 & 18.25 \\
\hline 60 & 6.87 & 7.79 & 89.96 & 18.35 \\
\hline SEm \pm & 0.21 & 0.21 & 2.11 & 0.25 \\
\hline $\mathrm{CD}(\overline{\mathrm{P}}=0.05)$ & 0.59 & 0.60 & 6.02 & 0.72 \\
\hline \multicolumn{5}{|l|}{ Thiourea } \\
\hline Control & 7.53 & & 113.93 & 14.80 \\
\hline $500 \mathrm{ppm}$ at branching & 10.02 & & 99.90 & 17.23 \\
\hline $\begin{array}{l}500 \text { ppm at } \\
\text { branching and flowering }\end{array}$ & 11.34 & & 89.49 & 18.12 \\
\hline $1000 \mathrm{ppm}$ at branching & 10.10 & & 97.70 & 17.28 \\
\hline $1000 \mathrm{ppm}$ at branching & 11.54 & & 88.69 & 18.47 \\
\hline $\mathrm{SEm}+$ & 0.27 & & 2.72 & 0.28 \\
\hline $\mathrm{CD}(\overline{\mathrm{P}}=0.05)$ & 0.76 & & 7.78 & 0.81 \\
\hline $\mathrm{CV}(\%)$ & 7.93 & & 8.33 & 5.70 \\
\hline
\end{tabular}

The beneficial role of thiourea sulphydryl compound in improving the translocation of photosynthates for yield formation has been proved in pot study under laboratory condition at BARC, Mumbai which concluded that the efficiency of transport of labelled sucrose (14-C) from stem to pod of mustard was increased by 35.1-44.1 with foliar spray treatments as compared to unsprayed control (Srivastava et al., 2008). Further, increase in biological yield as well as seed yield was the cumulative effect of improved growth parameters due to foliar spray treatments. Foliar spray of thiourea 500 ppm at branching and flowering remained at par with thiourea spray $1000 \mathrm{ppm}$ at branching and flowering. The increase in yield attributes and yield obtained with thiourea application was most probably due to increased crop photosynthesis favoured by both improved photosynthetic efficiency and source to sink relationship. Also, the increase in yield due to application of thiourea might be the result of concomitant increase in number of pods per plant, number of seeds per pod and plant growth characters viz. plant height, dry matter accumulation, number of nodules per plant, which are consistent with findings of (Meena and Sharma (2005) in mothbean and Bamaniya (2009) in mungbean. Thiourea $500 \mathrm{ppm}$ at branching and flowering fetched significantly highest net returns (Rs $52564 / \mathrm{ha}$ ) in comparison to rest of treatments.

Foliar spray of thiourea (Thiourea $500 \mathrm{ppm}$ at branching, $1000 \mathrm{ppm}$ at branching, $500 \mathrm{ppm}$ at branching and flowering and $1000 \mathrm{ppm}$ at branching and flowering) significantly increased the protein content, $\mathrm{N}$ and $\mathrm{P}$ concentration in seed and straw and total $\mathrm{N}, \mathrm{P}$ and $\mathrm{K}$ uptake by urdbean (Table 2) compared to control. Since, uptake of nutrients is the function of seed and straw yields and their concentration at cellular level and both resulted in enhanced uptake of nutrients. Thiourea application might have helped in improvement in metabolic processes of plants and better growth and development owing to greater absorption of nutrients from rhizosphere. It also might be due to metabolic 
role of SH-group in root physiology and biochemistry. Thiourea creates better microbial population in soil which are responsible to mobilize essential nutrients. These findings are in line with those of Meena and Sharma (2005) and Singh (2007). Application of thiourea $500 \mathrm{ppm}$ at branching and flowering registered significantly highest agronomic and apparent recovery of $\mathrm{P}$ than rest of treatments. Whereas, the highest phsiological efficiency recorded under control (Table 3).

\section{References}

Arora, D., 2004. Effect of thiourea and zinc on growth, yield and quality of barley (Hordeum vulgare L.) Ph.D. Thesis, Rajasthan Agricultural University, Bikaner.

Bamaniya, P.K., 2009.Effect of thiourea and zinc on productivity of mungbean [Vigna radiate (L.) Wilczek]. M.Sc. (Ag.). Thesis, Rajasthan Agricultural University, Bikaner.

Burman, U., Garg, B.K. and KathjuShyam 2008.Interactive effect of phosphorus, nitrogen and thiourea on clusterbean (Cyamopsis tetragonoloba L.) under rainfed condition of the Indian Arid Zone. Journal of Plant Nutrients and Soil Science, 170: 803-810

Jocelyn, P.C., 1972. Biochemistry of $-\mathrm{SH}$ group. The occurrence, Chemical properties, Metabolism and Biological Function of Thiols and Di-sulphides. Academic Press, London pp.44

Kumawat, P.K., Tiwari, R.C., Golada, S.L., Garhwal, R.K. and Choudhary, R. 2013. Effect of phosphorus sources, levels and biofertilizers on yield attributes, yield and economics of blackgram (Phaseolus mungo) Legume Research, 36: 70-73.

Kumawat, S.R., Khistriya, M.K., Yadav, S.L. and Kumar, M. 2014. Effect of phosphorus fertilization on yield, nutrient content, uptake and quality of summer greengram [Vigna radiata (L.) Wilczek]. Environment \& Ecology, 32(2A): 785-788.

Meena, B.S., and Sharma, D.D. 2005. Effect of phosphorus sources, solubilizers and bioregulators on growth, yield and $\mathrm{P}$ uptake by pigeonpea (Cajanus cajan). Indian Journal of Agronomy, 50:143145.

Rathore, D.S., Purohit, H.S. and Yadav, B.L. 2010. Integrated phosphorus management on yield and nutrient uptake of urdbean under rainfed conditions of southern Rajasthan, Journal of Food Legumes, 23(2): 128137.

Sahu, M.P., and Solanki, N.S. 1991.Role of sulphydryl compounds in improving dry matter partitioning and grain production of maize (Zea mays L.), Journal of Agronomy and Crop Science, 167:356359.

Sammauria, R., Yadav, R.S. and Nagar, K.C. 2009. Performance of clusterbean (Cyamopsis tetragonoloba) as influenced by nitrogen and phosphorus fertilization and biofertilizers in Western Rajasthan. Indian Journal of Agronomy, 54(3): 319-323.

Singh, B.R., 2007. Effect of thiourea and molybdenum on productivity of mothbean. [Vigna aconitifolia (Jacq.)] M.Sc. (Ag.) Thesis, Rajasthan Agricultural University, Bikaner.

Singh, G., and Sekhon, H.S. 2007. Effect of sowing methods and fertilizer application on growth and yield of kharif mungbean (In) National Symposium on Legumes for Ecological Sustainability: Emerging Challenges and Opportunities, 3-5 Nov. IIPR, Kanpur.

Srinivasarao, C.H., and Ali, M. 2006. Response of nutrient uptake of urdbean and mungbean genotypes to optimum 
nutrient supply on nutrient deficient sandy loam soil. Indian Journal of Pulses Research, 19 (2): 259-262.

Srivastava, A.K., Nathawat, N.S., Ramaswamy, N.K., Sahu, M.P., Singh, G., Nair, J.S., Paladi, R.K. and D' souza, S.F. 2008. Evidence for thiolinducel enhanced in site translocation of $14-\mathrm{C}$ sucrose from source to sink in Brassica juncea. Environmental and Experimental Botany, 64: pp 250-255.

Tanwar, S.P.S., Sharma, G.L. and Chahar, M.S. 2003. Effect of $P$ and biofertilizer on yield, nutrient content and uptake by blackgram (Vigna mungo). Legume Research, 26(1): 39-49.

\section{How to cite this article:}

Sanju Choudhary, O.P. Sharma, Gopal Lal Choudhary and Lali Jat. 2017. Response of Urdbean [Vigna mungo (L.) Hepper] to Phosphorus Fertilization and Thiourea on Yield, Quality, Nutrient Content and Uptake. Int.J.Curr.Microbiol.App.Sci. 6(10): 2841-2847. doi: https://doi.org/10.20546/ijcmas.2017.610.333 